\title{
腸內細菌の纎維素分解酵素に就いて
}

\author{
On the Cellulase of Bacteria isolated from \\ the human Intestine
}

國立笨養研究所

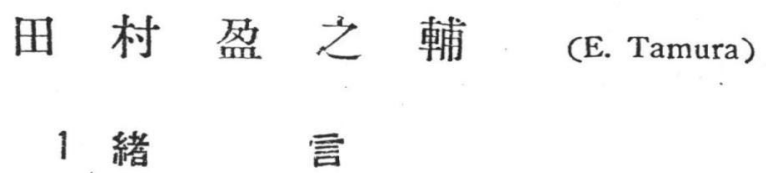

日本人食物は植物性食品が極めて多い。從つて, 纎維素の攝取量の多いのは當然である。殊 に, 最近の食䊓事情の惡化は日本人食內容の變遷を來し, 主食の質的纸下は副食の之れと相俟 つて, 織維素, その他の不消化成分の攝取が從來より遥かに增加したそ考えられる。㵶維素は 人體に攝取されても分解する消化腺分泌酵素は知られていないので, 吸收利用の過程は無い。腸 管內微生物の酵素により分解されて吸收せられ, 一部は人體の箖養に役立つ可能性があう。”

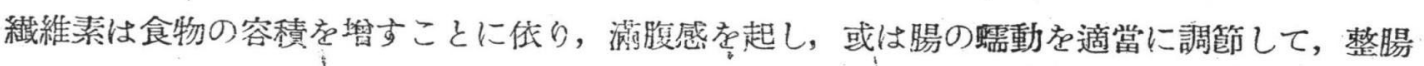
の效があるも，量の多すぎ万ときは，消化管の負擔它重くし，消化液を浪費するのみでなく，

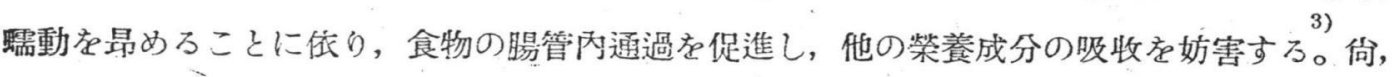
緎維素が腸內細菌の醉素に依り分解される場合には，この緎維素等に包未れた策養成分が，消 化液に觸れ分解されて吸收利用される事もある。即ち，食物中の纎維素は一定量は整腸の意味 で必要であるが,特に多量をとる必要はなく, 却て有害となることも考えられる。日本人を對象

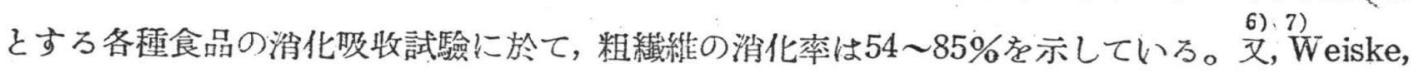
Knieriem, Wicke, Mann, Bárány 等に依つても, 各種植物性食品の粗瀻維の消化率は最高 $62 \%$ を示し，Lorischに估れば，䄉維素の消化率は，種々の野荣に依つて異り，最高 $100 \%$ を示

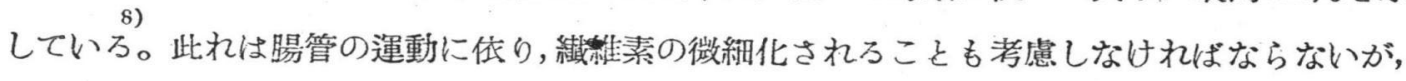
主として腸內細菌の酵素に依り分解されるものと考元られる。從つてこの腸內細菌に低る瀻維

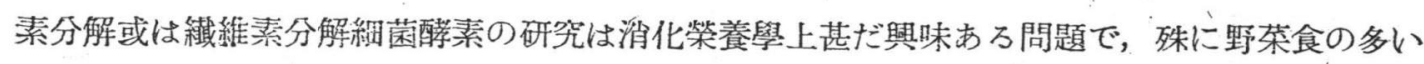
日本人については重要な研究課題である。

縤維素分解細菌に就いては1850年 Mitscherlichが水中に於て，細菌作用により馬鈴暮切片の 分解されることる證明したに初ら。以称多くの學者により, 瀻維素分解に關與する細菌に就い て䚋察され，又特殊の培養基により，之が分離が試みられている。併しながら人體に關して， 腸內細菌の瀻維素分解作用に就いての報告は卙い。Khouvine 女史, ${ }^{10}$ Causen, ${ }^{11}$ Hirschberg, 等の研究あるも，他は何れも，動物の消化管，土壤，堆肥，水等より分離された繊維素分解菌 
についての研究である。文献に記載されてい万主な万緎維素分解細菌としては, 次の如きちの が舉げられている。即ち, 婎氣性細菌としては Bacillus amylobacter(Van Tieghem), Bacillus fossicularum L. et N., Bacillus methanigenes L. et N. (Omeliansky), Bacillus cellulose dissolvens (Y. Khouvine), Clost. cellobioparus (Hungate), Clost. werneri (Werner), Clost. cellulosolvens (Cowles, Rettger), Terminosporus thermocellulolyticus (Pochon, Sarciron), Amylobacter navicula (Causen), Plectridium cellulolyticum (Pochon) 等で, 好氣性菌としては. Bacillus ferrigineus (Van Iterson), Micrococeus cytophagus, Micrococcus melanocyclus (Merker), Cellulomonas biazotea, Cell. aurogenes, Cell. galba, Cell. cellasea, Cell. caesia, Cell. pusilla, Cell. gelida, Cell. uda, Cell. acidula (Kellerman, McBeth, Scales, Smith), Cellulomonas rossica, Cell. flavigena (Kellerman, McBeth), Cellulomonas flava (Sack), Cellulomonas bibula, Cell. liquata, Cell. fimi (McBeth, Scales), Cellulomonas iugis, Cell. gilva, Cell. alma, Cell. concitata, Cell. albida, Cell. desidiosa, Cell. idonea, Cell. lucrosa, Cell. castigata (McBeth), Cellulomonas folia (Sanborn), Microspira agar-liquefacirus (Gray, Chalmers) 228 ) 29 ) born), Microspira agar-liquefacirus (Gray, Chalmers), Actinomyces cellulose (Krainsky), Cellufalcicula viridis, Cellufalcicula mucosa, Cellfalcicula fusca (Winogradsky), Cellulobacillus mucosa, Cellulobacillus myxogenes (Simola), Bact. cellulosolyticum flavum (Horwitz, Wlassowa), Cellovibrio ochraceus, Cellovibrio flavescens (Winogradsky), Cellovibrio fulvas, Cellovibrio vulgaris (Stapp, Bortels), Clost. cellulosae (Horwitz, Wlassowa), Cytophaga hutchinsoni, Cytophaga aurantiaca, Cyt. rubra, Cyt. lutea, Cyt. tunissima (Winogradsky), Cytophaga globulosa, Cyt. silvestris, Cyt. anularis, Cyt. crocea, Cyt. flavicula (Stapp, Bortels), Cytophaga myxococcoides (Krzemieniewska), Methanobacterium söhngenii, Methanobacterium omelianskii (Barker), Pseudomonas fibrolysis (大谷), Bac. mesent. hydrolyticus 等である。好熱性菌としては Clostridium thermocellum (Viljoen, Fred, Peterson), Bact. thermocellulyticus (Coalhaas), Bacillus thermofibrinocolus (板野, 荒川) ${ }^{44}$ 等である。又硝酸鹽還元細菌としては Bact. Opalescens, Bact. viscosum 等と Bact. Celloresolvens の共棲作用 (Groenwege) されていろ。細菌の纎維素分解酵素に就いては Pringsheim, Van Iterson, Karrer の研究が あろが，人體腸內細菌に就いての報告は葚小。

著者は人體腸內細菌に就いての繊維素分解酵素の檢討をする爲に, 先ず準腸內細菌と見做さ れ各種野生非病原性細菌に就いて, 繊維素分解酵素の分布を見た。侣, 人體腸內より分離され た蒟䓪マンナン分解有芽胞腸內細菌に就いて同樣の檢討を行つた。次いで，人體腸內より，新 に纎維素液化の强い好氣性細菌を分離し，その織維素分解酵素の檢討足行つた。

( 10$)$ 


\section{2 各種非野生非病原性細菌の維素分解酵素の分布}

(1) 實 驗 方 法

酵素液の調製：リービッと肉エギス $1.0 \mathrm{~g}$ ，ウイツテペプトン $1.0 \mathrm{~g}$ ，第 2 燐酸カリ $1.0 \mathrm{~g}$ ，溜水 ，100ec にて製した培養液 10ec 宛在試驗管に分注し，常法に從つて隇菌す。この唔養液に各種 野生非病原性細菌の各 1白金耳を移㮌し， $37^{\circ} \mathrm{C} の$ 䁔卵器に 2 日間納め，培盖したるものにトル オール數滴加えたもの在酵素液として使用す。

基質の調製：乾燥した市貶の精製貺脂綿を用い， R. Willstätter 及びL. Zechmeister 氏

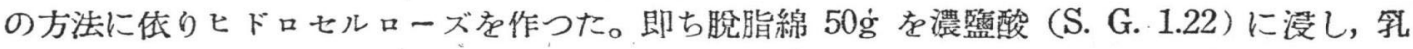

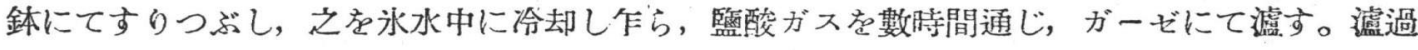
したものを水にて Cl 反應のなくなら迄水洗し，之を溜水に垤濁せしめて基質とした。このも のは 1ec の乾量 $34.83 \mathrm{mg}$, 銅價 3.7 , ヨード價 0.8 である。

定量方法：基質奬濁液 $2 \mathrm{cc}$ を前記酵素液中に入れトルォール數滴を加えて振り，密栓して， $37^{\circ} \mathrm{C}$ の孵卵器中に7日間納め, その年, 反應液 $5 \mathrm{cc}$ を取り, Schaffer-Hartmann 氏微量糖 49) 定量法に依り還元力を定量し，乏の還元力ね葡萄䌅 $(\mathrm{mg})$ を以て表わした。

(2) 實 驗 成 績

各菌株に就いて行つた實驗成續は第1表の如くである。

管 1 表

\begin{tabular}{|c|c|c|c|c|c|}
\hline 菌 & 株 & 還元值 & 菌 & 㧣 & 還元值 \\
\hline Bacillus cereus & （大原㸴） & $\begin{array}{c}(\mathrm{mg}) \\
0.247\end{array}$ & Bacillus petasites & (傳 咑) & $\begin{array}{c}\mathrm{mg}) \\
0.105\end{array}$ \\
\hline Bacillus fluorescens & (傳 研) & 0.571 & Bacillus subtilis & (釀 試) & 0.319 \\
\hline Bacillus fluorescens & (京大微) & 0.319 & Bacillus subtilis & (京大微) & 0.142 \\
\hline Bacillus liodermos & (千大微) & 0.507 & Acetobacter xylinus & 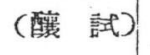 & 0.672 \\
\hline Bacillus megatherium & (傳 砳) & 0.344 & Proteus vulgaris & (傳 哳) & 0.157 \\
\hline Bacillus mesent. fuscus & (束大農) & 1.186 & Proteus mirabilis & (專 碰) & 0.357 \\
\hline Bacillus mesent. fuscus & (千大衛) & 0.408 & Proteus vulgaris & (京大微) & 0.344 \\
\hline Bacillus mesent. fuscus & (傳 砛) & 0.558 & Proteus zenkeri & (醷) 試) & 0.319 \\
\hline Bacillus mesent. niger & (覥 試) & 0.837 & Bacillus prodigiosum & (傳 研) & 0.784 \\
\hline Bacillus mesent. ruber & 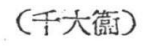 & 0.558 & Bacillus prodigiosum & (京大微) & 0.210 \\
\hline Bacillus mesent. ruber & (醅 試) & 0.571 & Bacillus prodigiosum coloi & ess (傳碑) & 0.157 \\
\hline Bacillus mesent. ruber & (傳 䂰) & 0.698 & Bacillus prodigiosum & (北 大) & 0.357 \\
\hline Bacillus mesent. vulgatus & (傳 砛) & 0.210 & Pseudomonas fluorescens & (傳 㸴) & 0.370 \\
\hline Bacillus mesent. vulgatus & 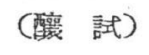 & 1.088 & Micrococcus candicans & （醇）試） & 0.902 \\
\hline Bacillus mesent. vulgatus & (京大徽) & 0.647 & Micrococcus urae & (釀 試) & 0.191 \\
\hline Bacillus pyocyaneum & (傳 硬) & 0.672 & Vibrio saprochiles & (釀 試) & 0.142 , \\
\hline Bacillus pyocyaneum: & (京大微) & 0.461 & Vibrio dentrificans & (傳 研) & 0.306 \\
\hline
\end{tabular}


(3) 總 括

ヒドロヒルローズを用いて, 各種野生非病原性細菌36株に就いて, 瀻維素分解酵素の分布を 見た。何れの細菌にも多少の存在展證明し，供試細菌中にては Bacillus mesent. fuscus（東 大㖘）が酵素が最も强く, Bacillus mesent. vulgatus（釀試）はこれに次ぐ作用を示した。

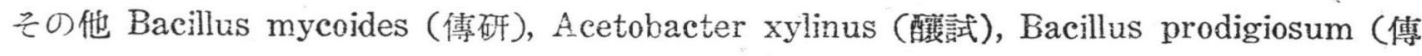

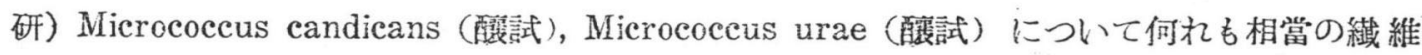
素分解酵素作用を認めた。

\section{3 蒟芴マンナン分解腸內細菌の織維素分解酵素に就いて}

(1) 實 驗 方 法

供試細菌：并上博士が人體腸內より分離した站蒻マンナン分解腸內細菌 8 株にして, その中

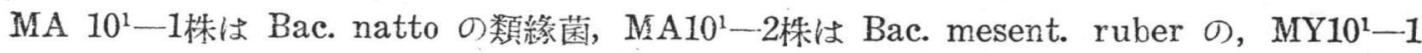
株は Bac. subtilis の何れも類䌜菌にして，他の分類上何れの菌にも相當せざるものという。 酵素液の調製：前記腸內細菌を新に培養し，これを堿菌 $\mathrm{K}_{2} \mathrm{HPO}_{4}$ 加肉エキスブイョン $50 \mathrm{cc}$ を分注した三角コルベンにて 2 日間培養し，忌の培養液をべルケフェルド細菌濾過器にて瀘過 したろ瀘液堂酵素液として使用した。

基 質: 前記のヒドロセルローズ㬾濁液を用いた。

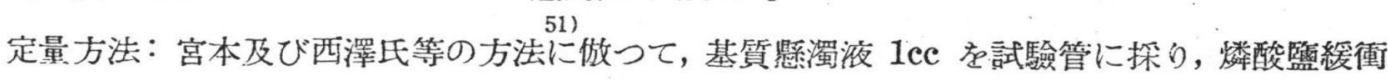
液 (pH6.8) 2ce, 酵素液 1 $\mathrm{cc}$ 宛を加え混合し, 少量のトルオールを加え密栓し, $37^{\circ} \mathrm{C} の$ 䁔卵器 中に納め，7日後にその全量在 Schaffer-Hartmann 氏微量糖定量法にて，前記同樣還元力を 測定し，葡萄糖（mg）を以て示した。

(2) 實 驗 成 績

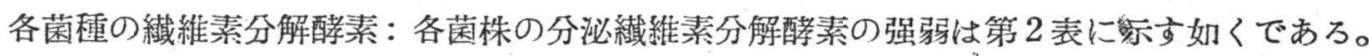

第 2 表

\begin{tabular}{|lr|c|c|}
\hline 菌 & 㭑 & 還元値 $(\mathrm{mg})$ & 作用時間 \\
\hline TK & $10^{2}-1$ & 0.698 & 90 \\
MY & $10^{1}-4$ & 0.477 & " \\
HS & $10^{1}-2$ & 0.532 & " \\
MA & $10^{1}-1$ & 0596 & " \\
MS & $10^{1}-2$ & 0.685 & $"$ \\
MS & $10^{1}-1$ & 0.591 & $"$ \\
MA & $10^{1}-2$ & 0.507 & 66 \\
MY & $10^{1}-1$ & 0.672 & 101 \\
\hline
\end{tabular}

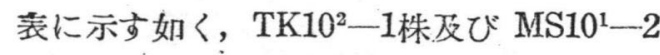
秼が比輘的强い繊維素分解酵素作 用を示し た。

至適 $\mathrm{pH}$ ：前記細菌の中酵素作用の最も强 いTK10²-1株に就いて, 至適 $\mathrm{pH}$ 学試驗した。 即ち 4.0-7.2の McIlveine 氏緩衝液を, 前記 の燐酸緩衝液の代りに加え， 7 日間 $37^{\circ} \mathrm{C}$ の率 卵器に納めたものにつき, 還元力を测定し,

第 3 表の結果を得た。 
第 3 表

\begin{tabular}{|c|c|c|c|c|c|c|c|c|}
\hline 菌株 & 4.0 & 4.5 & 4.8 & 5.4 & 6.0 & 6.5 & 6.8 & 7.2 \\
\hline TK $0^{2}-1$ & $\begin{array}{r}\mathrm{mg} \\
0.357\end{array}$ & 0.370 & 0.493 & 0.609 & 0.810 & 1.023 & 1.145 & 0.660 \\
\hline
\end{tabular}

表に示す如く $\mathrm{pH} 6.8$ に於て, 最高還元力を認めた。

至邀溫度: TK10²-1 株に就いて, 燐酸緩衝液 6.8 のもの存用いて, 㵶維素分解酵素の至適 溫度定檢し，只の結果は第 4 表の如くである。

表に示す如く $37^{\circ} \mathrm{C}$ に於て, 最高還元力定示 した。

（3）總括

人體腸內より分離された站䓪マンナン分解腸

內細菌 8 株の瀻維烮分解酵系作用蛋認め, その

\begin{tabular}{l|r|r|r}
\multicolumn{2}{c}{4} & \multicolumn{1}{c}{ 表 } \\
\hline
\end{tabular}

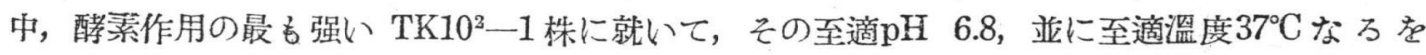
稚めた。

\section{4 腸內より分離せる好氣性細菌の緎維素分解酵素に就いて}

（1）被檢者並に試料

被檢者は總べて米飯を主食として，胃腸障䅞を認めない健康男女 4 名である。腸內細菌の試 料に就いては一般常法に從い，糞便細菌に就いて腸內細菌学檢す万方法在探つた。從つて嚴密 に云えば粪便細菌である。勿論, 糞便細菌は腸內細菌と異ろが, 糞便細菌は腸內細菌の主要な ろものである。粪便は滅菌シャーレに排便㞱しめて, 可及的無菌的に探便した。被檢者並に霬 便の性狀に就いては第 5 表に示す如くである。

(2) 繊維素液化菌の分離

腸內細菌より瀻維素液化力强き好氣性菌壁檢 索す万雼に，豫め試驗管中に長さ約 $3 \mathrm{~cm}$, 幅約 $0.5 \mathrm{~cm}$ 濾紙片を入れた McBeth ${ }^{52)}$ 及び Dubos の培養基各 5ec の常法により滅菌したものに, 新鮮㱳便の1白金耳移櫃し, $37^{\circ} \mathrm{C}$ の孵卵器に 納め, 每日輕く振盪し, 瀘紙片の液化の度を對 照と比較した。その結果は第6表の如くである。

\begin{tabular}{|c|c|c|c|c|c|}
\hline \multirow{2}{*}{ 被檢者 } & \multirow{2}{*}{ 性 } & \multirow{2}{*}{$\begin{array}{l}\text { 年 } \\
\text { 路命 }\end{array}$} & 䔬 & 便 & 狀. \\
\hline & & & 硬 度 & 色 澤 & 臭 氣 \\
\hline A & 女 & 35 & 普 通 & 黃 褐 & 異 臭 \\
\hline B & 男 & 35 & $"$ & " & 弱 \\
\hline C & 女 & 24 & 軟 & " & " \\
\hline $\mathrm{D}$ & 男 & 46 & " & " & " \\
\hline
\end{tabular}


液化は20日間に亘つて觀察したが，瀘紙片は何れの被檢 者の場合も液化したので，此の液の一部を採り，ベルトラ ン氏法により還元力を見たが，甚だ弱かつた。用いた培養 基の組成は次の如くである。

\begin{tabular}{|c|c|c|}
\hline 被檢者 & McBeth & Dubos \\
\hline A & 册 & $\#$ \\
\hline B & 世 & \# \\
\hline $\mathrm{C}$ & 世 & + \\
\hline D & 㱐 & \# \\
\hline
\end{tabular}

\begin{tabular}{|c|c|c|c|}
\hline \multirow[t]{3}{*}{ McBeth } & 培羑基 & $\mathrm{MgSO}_{4} \cdot 7 \mathrm{H}_{2} \mathrm{O}$ & $1.0 \mathrm{~g}$. \\
\hline & & $\mathrm{NaCl}$ & $1.0 \mathrm{~g}$. \\
\hline & & $\mathrm{CaCO}_{3}$ & $2.0 \mathrm{~g}$. \\
\hline \multirow[t]{3}{*}{ Dubos } & 培垰基 & $\mathrm{NaNO}_{3}$ & $0.5 \mathrm{~g}$. \\
\hline & & $\mathrm{KCl}$ & $0.5 \mathrm{~g}$. \\
\hline & & $\mathrm{K}_{2} \mathrm{HPO}_{4}$ & 1.0 \\
\hline
\end{tabular}

McBeth 琣食基にて瀘紙片の液化を認めたもの存, 同培 養基に 2 回繰返して㮌え, 前同樣の液化を確めた上, 細菌 の分離を試みた。即ち, 液化培地をよく振り, その 1 白金 耳支滅菌生理的食監水 5cc.にうすめ, その0.01-0.02ccを McBeth 寒天培豢基に Drigalski 棒にて本等によく塗沫 し, $37^{\circ} \mathrm{C}$ の孵卵器中に 3 日間納め, 平板上に出現した衆落 中，肉眼的に異ると思われるもの在釣菌し，これを $\mathrm{Mc}-\mathrm{Be}$ th 培養基に前同樣に瀘紙片后入れたものを減菌したもの に移植して，瀘紙の液化を14日間に亘つて觀察した。その 結果は第7表の如くである。

$\begin{array}{ll}\mathrm{K}_{2} \mathrm{HPO}_{4} & 1.0 \mathrm{~g} . \\ \left(\mathrm{NH}_{4}\right)_{2} \mathrm{SO}_{4} & 2.0 \mathrm{~g} . \\ \text { 溜 水 } & 1000.0 \mathrm{cc} . \\ \mathrm{MgSO}_{4} \cdot 7 \mathrm{H}_{2} \mathrm{O} & 0.5 \mathrm{~g} . \\ \mathrm{FeSO}_{4} \cdot 7 \mathrm{H}_{2} \mathrm{O} & 0.01 \mathrm{~g} . \\ \text { 溜 水 } & 1000.0 \mathrm{cc} .\end{array}$

第 7 表

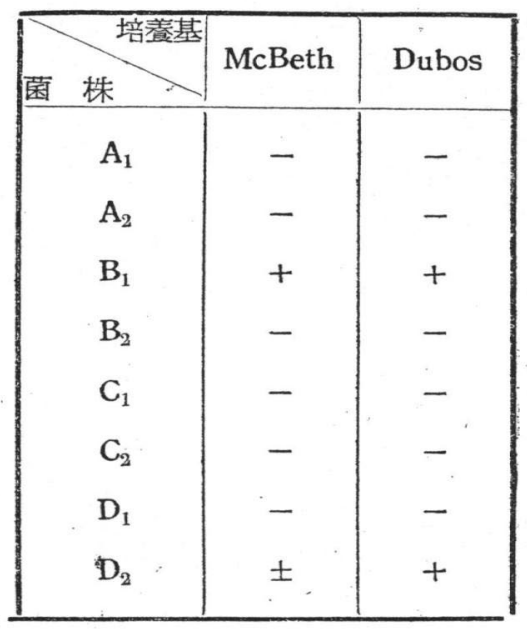

表に示す如く，瀘紅の液化は分離前よりも惡い。各々分離された 2 種の細菌は，肉汁培養液 中の硝酸鹽を還元す万爲に，此の 2 種の細菌は Groenwege の云う共棲作用をしないと考えら れる。分離菌の中, 液化菌2株に就いて一般細菌學的性狀並に繊維系分解酵素の性狀を檢討した。

（3）分離菌の一般細菌學的性狀

1) 一般生物學的性狀 菌の形熊, グラム染色, 運動に就いては, 肉汁寒天杀面12一24時間 琣養のものに就いて檢し，芽胞は同寒天斜面 24-36 時間培養のものに就いて檢した。ラクム ス牛乳培養基によつて㠜固, 脫色, 渻化に就いて檢し，インドール反應は $2 \%$ 照內ペプトシ 加肉汁培地の3 日及び7,日培養のものに就いて, Wallace and Neave 兩氏の Sulfanilic acid Dimethyl- $\alpha$-naphthylamine 法にて檢した。硫化水慕發生は醋酸鉛紙を肉汁培養基の試驗管 內に吊し，綿栓にて支えて黑變すらゃ否やを見た。その結果は第 8 表に示す如くである 
第 8 表

\begin{tabular}{|c|c|c|c|c|c|c|c|c|c|c|c|}
\hline \multirow{2}{*}{$\begin{array}{l}\text { 菌 } \\
\text { 株 }\end{array}$} & \multirow{2}{*}{$\begin{array}{l}\text { 棞 } \\
\text { 形 }\end{array}$} & \multirow{2}{*}{ 運 } & \multirow{2}{*}{$\begin{array}{l}\text { 大 } \\
き \\
さ(\mu)\end{array}$} & \multirow{2}{*}{$\begin{array}{l}\text { グ } \\
\text { ラ } \\
\text { 染 } \\
\text { 色. }\end{array}$} & \multirow{2}{*}{$\begin{array}{l}\text { 芽. } \\
\text { 胞 }\end{array}$} & \multirow{2}{*}{$\begin{array}{cc}\text { 牛 } & \\
& \text { 万 } \\
& \text { 厶 } \\
\text { 乳 } & \text { 下 }\end{array}$} & \multicolumn{2}{|c|}{ ゼラチン } & \multirow{2}{*}{$\begin{array}{l}1 \\
y \\
5 \\
1 \\
u\end{array}$} & \multirow{2}{*}{$\begin{array}{r}\text { 還硝 } \\
\text { 酸 } \\
\text { 元㰓 }\end{array}$} & \multirow{2}{*}{$\begin{array}{l}\text { 硫 } \\
\text { 化 } \\
\text { 水 } \\
\text { 素 }\end{array}$} \\
\hline & & & & & & & $\begin{array}{l}\text { 液 } \\
\text { 华 } \\
\text { 度 }\end{array}$ & $\begin{array}{l}\text { 液 } \\
\text { 帒 } \\
\text { 形 }\end{array}$ & & & \\
\hline $\mathrm{B}_{1}$ & 桿 & + & $\begin{array}{c}1.74- \\
3.48 \times \\
0.92\end{array}$ & + & + & $\begin{array}{l}\text { 輕 消 } \\
\text { 徽 } 2 \\
\text { 凝日 } \\
\text { 固 } \\
\text { 完 }\end{array}$ & H & 曆 & - & + & + \\
\hline$D_{2}$ & $\begin{array}{l}\text { 秙 } \\
\text { 狀 }\end{array}$ & + & $\begin{array}{c}4.06- \\
4.80 \times \\
1.16\end{array}$ & + & + & $\begin{array}{l}\text { 輕 } \\
\text { 徽 } \\
\text { 㠜日 } \\
\text { 固完 }\end{array}$ & \# & $\begin{array}{l}\text { 厚 } \\
\text { 牀 }\end{array}$ & - & + & + \\
\hline
\end{tabular}

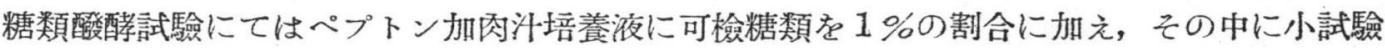
管を倒立せしめたものを，常法に從つて滅菌し，分離菌を移植し，20日間に亘り酸並にガス發

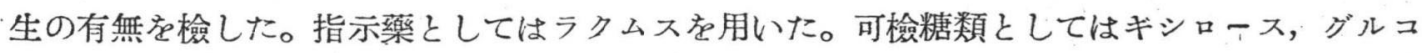
ース, マンノース, フラクトース, サッカロース, デギストリン, 激粉, 乳糖, イメリン, マ ンニット，ズルチット，グリセリン等である。

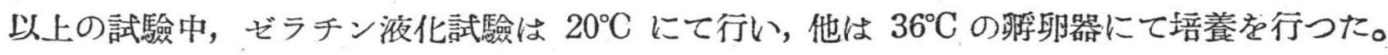
その結果によれば，何れの菌株にても，酸發生又ガス發生を認めなかつた。

2）各種培養基上に於ける性狀 培養基としては寒天培養基，馬鈴薯培養基及び肉汁培養基 を用いた。寒天培養基にては平板塗洙培養, 斜面劃線培食に就いて觀察した。乞の結果は第 9,10 表に示す如くである。

第 $\quad 9 \quad$ 表

\begin{tabular}{|c|c|c|c|}
\hline 菌株 & 寒天 本板塗嫲培圽 & 寒 天 科 面 培 養 & 寒天高曆穿刺培養 \\
\hline $\mathrm{B}_{1}$ & 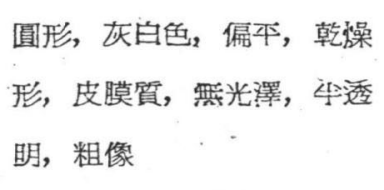 & $\begin{array}{l}\text { 最初絲狀，後樹枝壯，灰白 } \\
\text { 色，稍及帶黃 }\end{array}$ & 線 \\
\hline $\mathrm{D}_{2}$ & 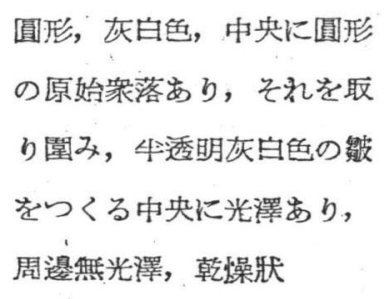 & $\begin{array}{l}\text { 最初絲壯, 後樹枝狀, 灰白 } \\
\text { 色 }\end{array}$ & 狀 \\
\hline
\end{tabular}




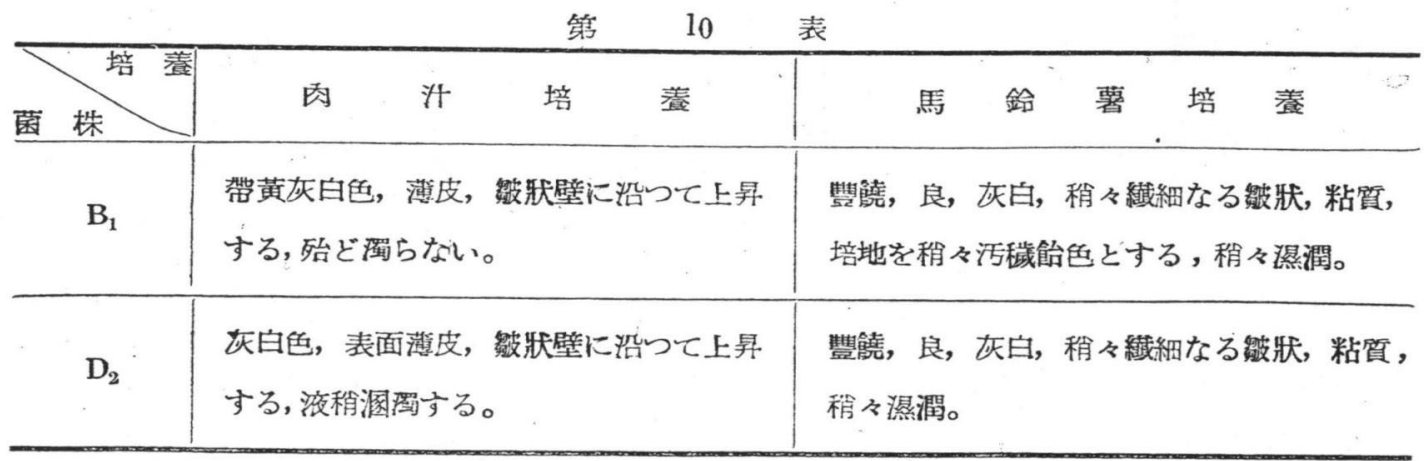

3）分離細菌の朁知細菌上の位置 分離細菌は 2 株ともに有芽胞性桿狀菌である。一般細菌 學的性狀より菌形を制定する゙ば, 馬鈴薯菌に近似するも一致しない。

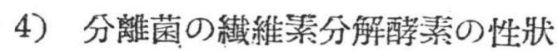

1）基質の調製 ${ }^{55)}$ 炭酸銅 $75 \mathrm{~g}$ を含め万溜水 $250 \mathrm{cc}$ k $\mathrm{NH}_{4} \mathrm{OH}$ (S. G. 0.90) 1L に混合溶

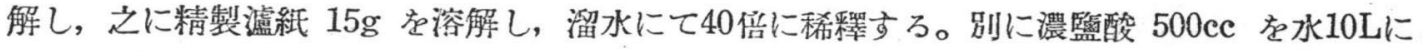
加えたものを前記溶液 10Lに徐々に混合すれば, 繊維素は絮狀に沈澱する。此の沈澱を集め, $\mathrm{Cu}$ 及び $\mathrm{Cl}$ 反應のなくなる迄よく洗い, 溜水に浮遊せしめたもの在基質液とした。此の基質 液の漫度は $0.47 \mathrm{~g} / \mathrm{dl}$, 銅價 1.62, 沃度價 2.67 である。

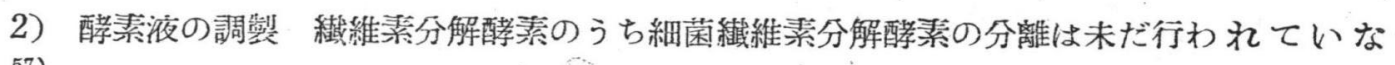
$57)$ い。著者は菌體を自家融解せしめめて酵素液とする方法を探つた。即ち，直徑 $9 \mathrm{~cm}$ のシャーレ 20 枚に肉汁寒天培養液 $15 \mathrm{cc}$ を入れ, 常法に從つて堿菌したものに分離菌を植え, $36^{\circ} \mathrm{C}$ の孵卵 器に3-4日納め, その菌體を 50cc の溜水にて洗い集め, トルオールを加え, 再び $36^{\circ} \mathrm{C}$ の睬 卵器に24時間納めて, 自家融解せしめた。自家融解液を遠心沈湏して, その上清を膀胱膜に入 れて 2 日間透析したもの酵䇣液とした。この液は稍々褐色を帶びた牛透明の液である。

3）定量方法 宮本及び西澤氏等の方法に倣つて，基質液 1cc，酵素液 1cc，Mcllveine 氏 緩衝液 2ce 在試驗管に採り, トルオール數滴を加え, 密栓して $36^{\circ} \mathrm{C}$ の孵卵器に7日間納め, その全液の還元力を Schaffer-Hartmann 氏微量糖定量法にて定量し，葡萄糖（mg）を以 て表した。

4) 至適溫度 分離菌の繊維素分解酵素の至適溫度を見万爲に， $\mathrm{B}_{1}$ 株には $\mathrm{pH} 5.8, \mathrm{D}_{2}$ 侏に は $\mathrm{pH} 5.2^{\prime} の$ McIlveine 氏緩衝液を用い, $30^{\circ} \mathrm{C}, 36^{\circ} \mathrm{C}, 45^{\circ} \mathrm{C}$ の䁔卵器在使用して，7日間前記 方法により酵素を作用せしめて，全液の還元力を見た。その結果は第11表に示す如く，何机の 菌株も $36^{\circ} \mathrm{C}$ で最强還元力を示した。 
5）至適 $\mathrm{pH}$ 分離菌の纎維素分解酵素の至 適 $\mathrm{pH}$ を見万爲に $\mathrm{pH} 4.0-7.0$ の系列の $\mathrm{Mc}$ -

Ilveine 氏緩衝液を用いて, $36^{\circ} \mathrm{C}$ の孵卵器にて 7 日間, 前同樣酵素液を作用せしめて, 還元力 を見たのに第12表に示す如くである。 第 11 表

\begin{tabular}{|c|c|c|c|}
\hline 菌林 & $30^{\circ} \mathrm{C}$ & $36^{\circ} \mathrm{C}$ & $45^{\circ} \mathrm{C}$ \\
\hline $\begin{array}{c}\mathrm{B}_{1} \\
\mathrm{pH} 5.8\end{array}$ & $0.182 \mathrm{mg}$ & 0.220 & 0.142 \\
\hline $\begin{array}{c}\mathrm{D}_{2} \\
\mathrm{pH} 5.2\end{array}$ & $0.073 \mathrm{mg}$ & 0.115 & 0.077 \\
\hline
\end{tabular}
表に示す如く $B_{1}$ 株にては $\mathrm{pH} 5.8, \mathrm{D}_{2}$ 株にては $\mathrm{pH} 5.2 の$ 附近に至適 $\mathrm{pH}$ が存在する。 以後の實驗には, $\mathrm{B}_{1}$ 株にはpH $5.8, \mathrm{D}_{2}$ 株には $\mathrm{pH} 5.2$ の何れ も McIlveine 氏緩衝液を用い

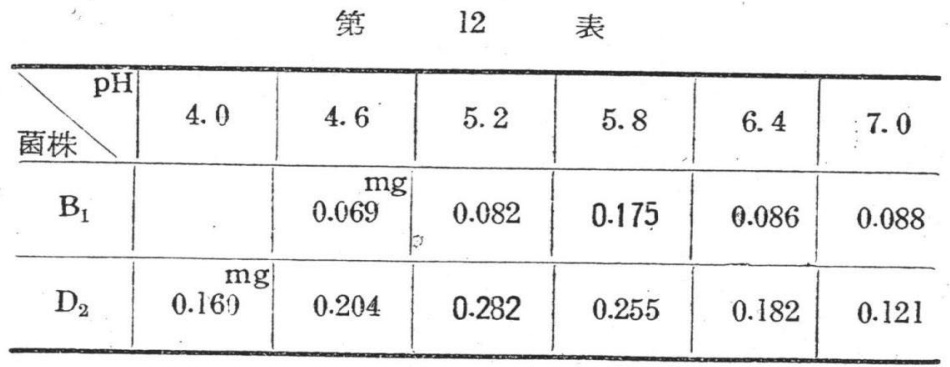
た。

6）振盪の影響 分離菌の繊維素分解酵素に及ぼす振盪の影響を見る爲に, $\mathrm{D}_{2}$ 株酵素液に就 いて, $36^{\circ} \mathrm{C}, 7$ 日間, 前同樣に酵素を作用せしめ，その間守日1-3回振盪し，その影響を見た。 その結果は第13表に示す如く, 3 回振盪したものが最强還元力を示した。

7) 中性監類の影響 分離細菌の繊維素分解酵素に及 ぼす各稴中性監類の影響を見る雼に, $\mathrm{B}_{1}, \mathrm{D}_{2}$ 株酵素液に 各々 $\mathrm{pH} 5.8, \mathrm{pH} 5.2$ の Mcllveine 氏緩衝液を加え, 前 記同條件のもとに酵素卆作用せしめた。

陽イオン：試驗せるイオンは1價イオン $\mathrm{Na} ; \mathrm{K}, \mathrm{Mg}^{\circ}$ 第 13 表

\begin{tabular}{|c|c|c|c|}
\hline 菌株 & 0 & 1 & 3 \\
\hline $\mathrm{D}_{2}$ & $\begin{array}{c}\mathrm{mg} \\
0.134\end{array}$ & 0.238 & 0.279 \\
\hline
\end{tabular}

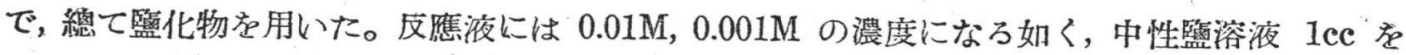
加えた。對照として溜水 1cc を加えたものと比較した。その結果は第14表に示す如くである。

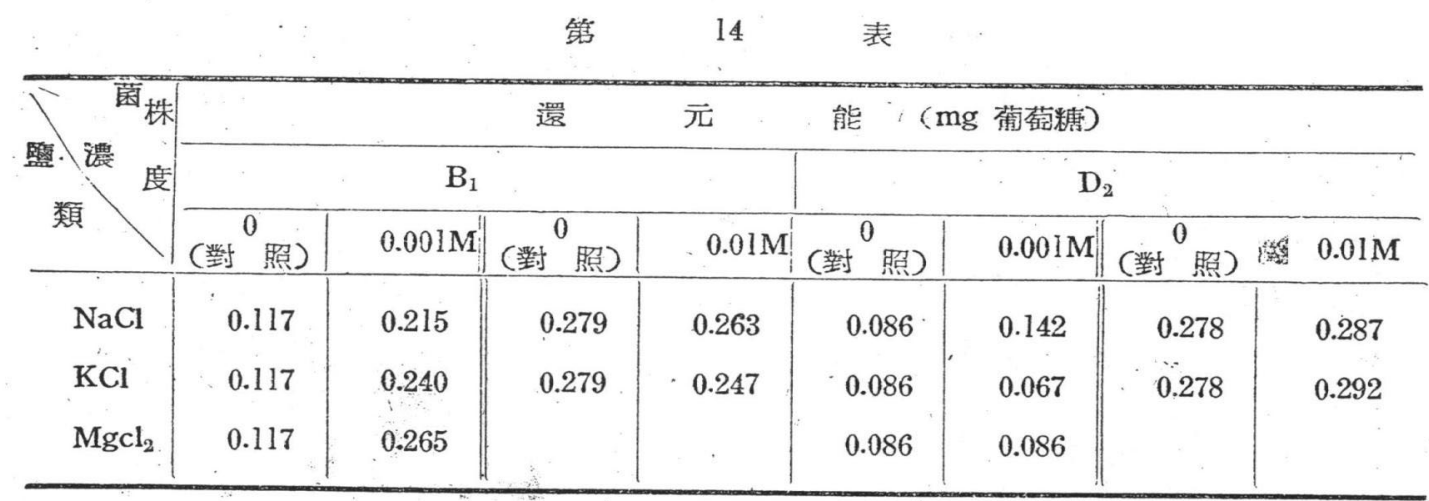

陰イオン：陽イオンの場合を同樣の試驗方法により $\mathrm{Cl}^{\prime}, \mathrm{F}^{\prime}, \mathrm{J}^{\prime}, \mathrm{NO}_{3}{ }^{\prime}, \mathrm{SO}_{4}{ }^{\prime \prime}$ の影響名見 ( 17 ) 
た。而して，總てNa監を用いた。その結果は第15表に示す如くである。兩試驗に於て $0.001 M$

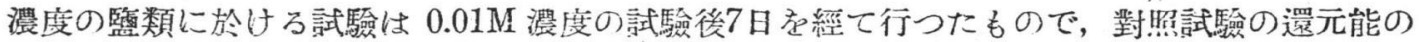
洷は，時日と共に酵素力の急速な減少を示している。

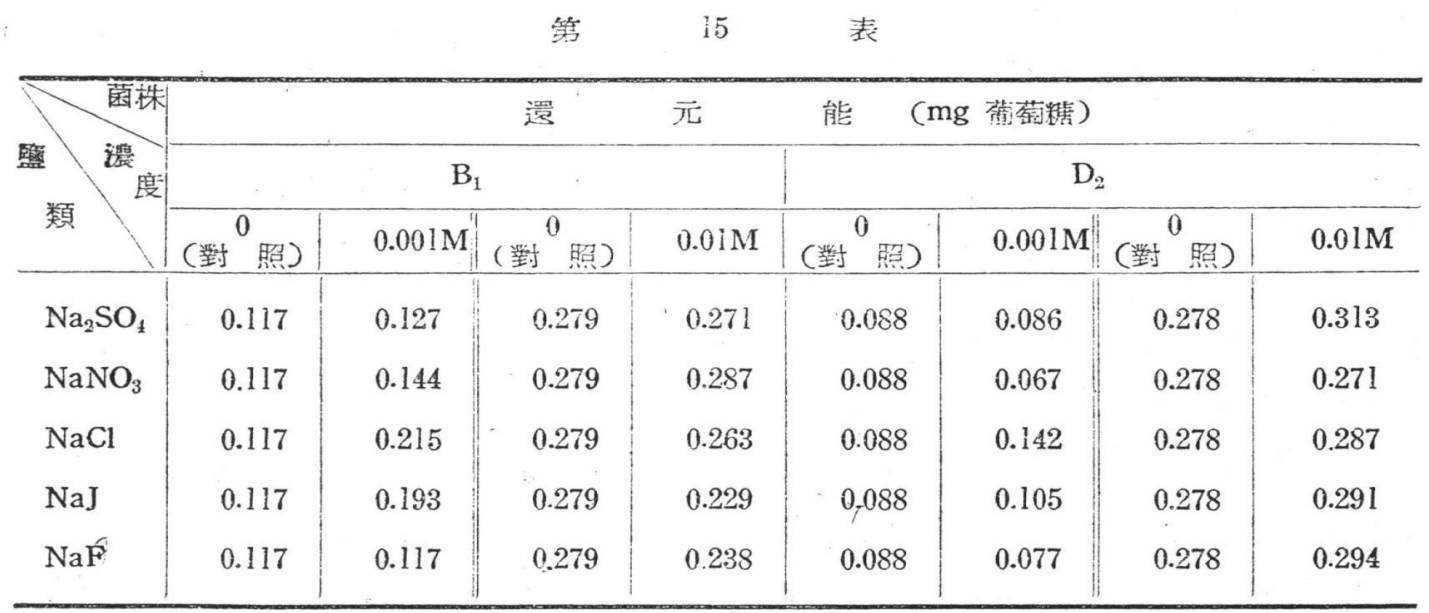

以上の結果より分離菌の瀻維素分解酵素に及ぼす中性鹽類の影響は，試驗せる各種監類に就

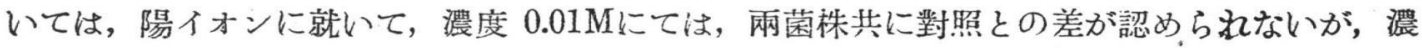
度0.001Mにては $\mathrm{B}_{1}$ 株は $\mathrm{Na}$ ， $\mathrm{K} ， \mathrm{Mg} \cdot$ 共に, 繊維素分解作用を稍々促進するが， $\mathrm{D}_{2}$ 株にて は $\mathrm{Na}$ のみ稍及促進し，他は對照と比し差が認められない。陰イオンに就いても，䀼度 $0.01 \mathrm{M}$

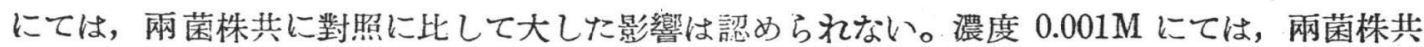
に $\mathrm{Cl}^{\prime}$ のみが稍々促進的作用ある傾向が認められ，他は對照と大差を認めない。

8）アミノ酸, ステアリン酸, グリセリン，スカトールの影響 䁑內に於て各種のアミノ酸, 脂肪酸、グリセリン，スカトール等の生ずる爲に，之の繊維素分解作用に及ぼす影響を見た。 即ち，アミノ酸としては，ロイシン，チロジン，グリココール，ヒズチヂン，アスバラギン酸， グルタミン酸等にて，その他ステアリン酸，グリセリン，スカトール等を用いた。前記同樣の 作用條件にて，反應液に0.01M になる如くアミノ酸水溶液を1ec加えたもの虏主實驗とし，溜 水を加えたものを對照として試驗し，比較した。但しチロジン，ステアリン酸，スカトール等 は飽和液を用いた。その結果は第16表に示す如くである。

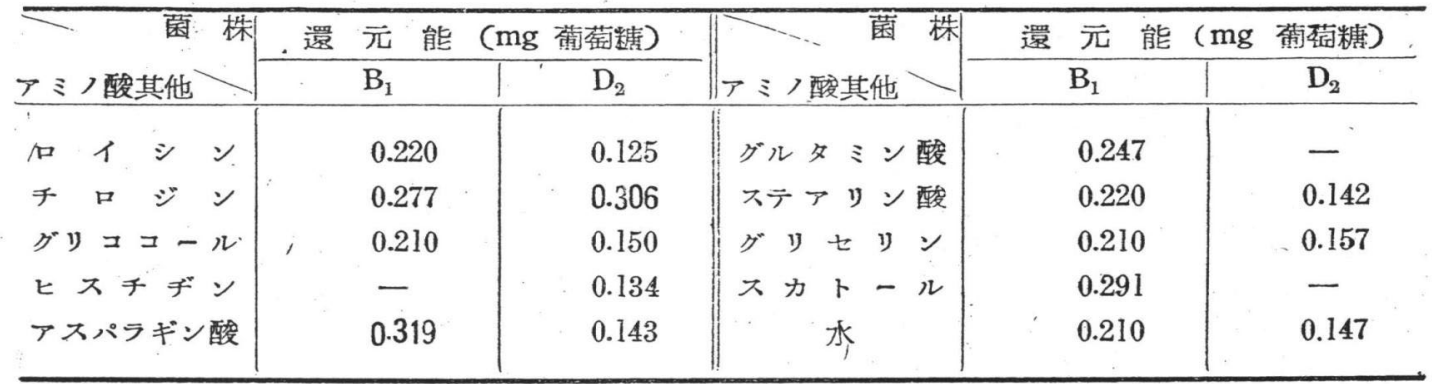


表に示す如く, 瀻維素分解作用に對して， B 1 株にてはアスパラギン酸, チロジン, スカトー ルが對照に比して稍々促進的に作用し，他は何れも對照に比して大差が認めら秃ない。 $\mathrm{D}_{2}$ 株に 就いてはチロジンが稍及促進的に作用する他は，前同樣大差が認められない。

(5) 總括並に教察

健康男女 4 名の営便より, 繊維素液化力强き好氣性有芽盷細菌を分離し, その細菌學的一般 性狀を檢したのに，馬鈴䛓菌に近似しているがこれと全く一致すると言えない。馬鈴薯菌の一 種にて緎維素在分解するB. mesent. hydrolyticus があるも, こ礼とも異る樣である。又最

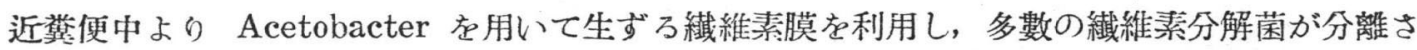
れていろ。

著者は分離細菌の繊維素分解酵素に就いて檢討したのに, 至適溫度 $36^{\circ} \mathrm{C} に$, 至適酸度は pH5.8 ( $\mathrm{B}_{1}$ 株), 又 PH5.2 ( $\mathrm{D}_{2}$ 株) の附近に存する樣である。又 $\mathrm{D}_{2}$ 株に就いて振晹の影響克見 たのに 1 日 3 回以下では, 3 回が最高の還元力を示した。これは主として基質の分散を起す䉆

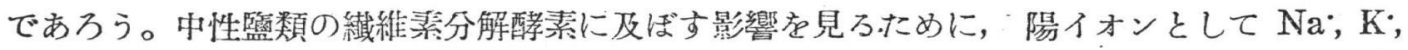

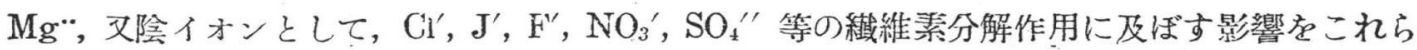
を加えない對照と比較した。 $\mathrm{B}_{1}$ 並に $\mathrm{D}_{2}$ 株ともに0.01M の蕽度にては，陰陽イオン共にその

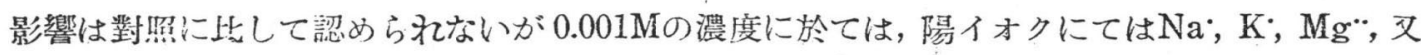
$\mathrm{D}_{2}$ 株にては $\mathrm{Na}$ が對照に比して分解作用を稍々促進すると思われる。陰イオンに就いては $0.001 \mathrm{M}$ の湄度にて, 兩菌株共に $\mathrm{Cl}^{\prime}$ のみが稍々促進的に作用する結果となつた。各㮔のアミ ノ酸, 即ち, チロジン, ロイシン, グリココール, ヒスチヂン, アスパラギン酸, グルタミン 酸等, 又, ステアリン酸, ク゚リセリン，スカトール等，腸冈にて生ずると思われるものの繊維 素分解酵素に皮ばす影響を見たのに， $\mathrm{B}_{1}$ 株にてはアスパラギン酸，チロジン，スカトール等， 又 $\mathrm{D}_{2}$ 株にてはチロジンが稍々促進的に作用する影響を示した。他は何れも對照と比して大差 が認められない。

著者の分離菌の酵素液は，時日と共に酵素力は急速に弱くなる榚である。又，分離菌より製 した酵素液によろ瀻維素の分解迹物を見んとして，反應液より，葡萄糖又はセロビオースの檢 出を行つたが成功しなかつた。

\section{5 摘 要}

1）各種野生非病原性細菌36株に就いて，繊維氶分解酵素の分布を見たのに，何れの細菌に も多少共存在し，特に Bacillus mesgnt. fuscus (東大農), Bacillus mesent. vulgatus (醽 試）が酵系力强きが認められた。

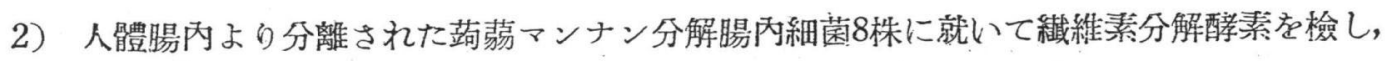
その中, 酵系力最も强き TK $10^{2}$-1株に就いて, 至適溫度 $36^{\circ} \mathrm{C}$, 至適 $\mathrm{pH} 6.8$ なろを認めた。 
3）健康男女 4 名の㱳便より，纎維素液化力强き好氣性有芽細菌 2 株を分離し，その一般 細菌學的性狀虎檢したのに馬鈴薯菌に近似す万も一致しない。

4）分離細菌を自家融解せしめて製した酵㨞液より，瀻維素分解酵素の性狀を檢した。

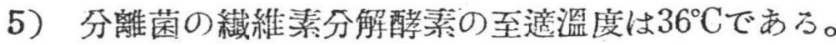

6）分離菌の瀻維素分解酵糸の至扂酸度はB株にては $\mathrm{pH} 5.8$, 又 $\mathrm{D}_{2}$ 株にてはpH5.2である。

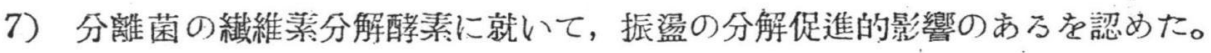

8）分離菌の瀻維素分解酵奚に及ぼす中性監類の影摡を見たのに，陽イオンにては $\mathrm{B}_{1}$ 株に 於ては， $\mathrm{Na} ; \mathrm{K} ; \mathrm{Mg} *$, 又 $\mathrm{D}_{2}$ 秼にては $\mathrm{Na}$ が稍々促進的に作用し，㓌イオンにては $\mathrm{B}_{1}$ 並 に $\mathrm{D}_{2}$ 株共に $\mathrm{Cl}^{\prime}$ が稍々促進的に作用する。

9）分離菌の繊維素分解酵奚に及ぼすアミノ酸，ステアリン酸，グリセリン，スカトール等 の影響を檢したのに， $\mathrm{B}_{1}$ 株にてはアスパラギン酸; チロジン，スカトール，又， $\mathrm{D}_{2}$ 株にてはチ ロジンが稍タ促進的影響を示した。

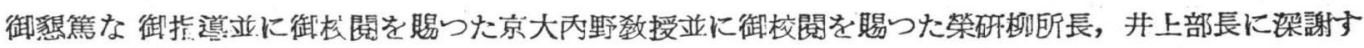
る。合實驗に助力を惜しまれなかつた長尾哲子，高居百合子兩氏に謝意を表する。

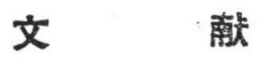

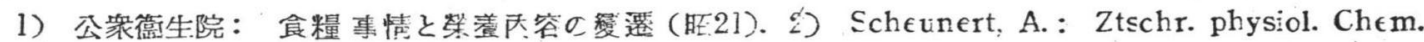
48, 9 (1906). 3) 中川：榮着緬論 36 (昍28). 4) Pringsheim, H. : Ztschr. physiol. Chem. 78, 266 (1912). 5) Ne uberg, C., Cohn, R.: Biochem. Ztschr. 139, 528. (1923). 6) 田村, 田中, 荘

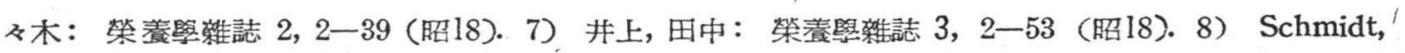
Ad.: Die Fäzes des Menschen 219 (1915). 9) Waksman: The principles of soil microbiology 190 (1927). 10) Khouvine, Mm Y.: Ann. inst. Pasteur 37, 711 (1923); Chem. Abst. 18, 281 (1924). 11) Ca usen, P.: Cent. Bakt. II, 84, 20 (1931). 12) Hirschberg, N.: Am. J. Digest. Dis. 9, 200 (1912); 酸酵工業外或交塥抄 1,3-4 (昭23). 13) Van Tieghem, P.E.L.: Waksman, The principles of soil microbiology 191 (1927). '14) Omeliansky, W. L. : Cent. Bakt. II, 8, 353 (1902). 15) Hungate, R.E.: J. Bact. 48, 499 (1944). 16) Werner E.: Cent. Bakt. II, 67, 297 (1926), Bergey's manual of determinative bacteriology 785, 5th ed. (1939). 17) Cowles, P.B.: Rettger L. F.: J. Bact. 21, 167 (1931). 18) Pochon, J., Sarciron, R.: Compt. rend. 216, 219 (1943); 酸醉工業外國交献抄 1.6 (昭23). 19) Pochon： Ann. Inst. Pasteur, 55. 676 (1935); 小原：應用微生物學各論 205 (昭23). 20) Van Iterson, C.： Cent. Bakt. II, 11, 689 (1904). 21) Merker: Cent. Bakt. II, 31, 578 (1912). 22), 23), 24), 25), 26), 27); Bergey's manual of derminative bacteriology 5th ed. 487 1939). 28) Gray, P. H. H., Chalmers, C.H.: Ann. 
Appl. Biol. II, 324 (1924); Chem. Abstr. 19, 2512 (1925). 29)Krainsky: Cent. Bakt. II,662 (1914); Bergey's manual of determinative bacteriology 5th ed., 851 (1939). 30) Winogradsky: Ann. Inst. Pasteur. 43, 549. (1929); Chem. Abstr. 24, 3309 (1930). 31) Simola, P.E.: Ann. Acad. Sci. Fenn. Ser. A 34, 1, 1; Chem. Abstr. 25, 4575 (1931). 32) Horwitz, Wlassowa: Cent. Bakt. Parasit, II, 93, 347 (1936; Chem. Abstr. 30. 3855 (1936). 33) Winogradsky : Bergey' s manual of determinative bacteriology 5th ed., 118 (1939). 34) Stapp, Bortels: Cent. Bakt. II, 90, 42 (1934); Bergey's manual of determinative bacteriology 5th ed., 119 (1939). 35) Horwitz, Wlassowa: Cent. Bakt. II, 94, 240 (1936). 36) Winogradsky: Ann. Inst. Pasteur, 43, 578 (1929); Bergey's manual of determinative bacteriology 5th ed.947 (1939). 37) Stapp, Bortels: Cent. Bakt. II, 90,28 (1934); Bergery's manual of determinative bacteriology 5th ed., 948 (1939). 3S) Krzeieniewska：Arch. Microb. 4, 394 (1933); 小原； 萑用微生物學各論 207 (昭23). 39) Barker：Arch. Microb. 4, 394 (1933); 小原：鷹用微生物學各論 207 (昭23). 40) 大谷：釀造誌 7. 24 (炤4). 41) Hormann, S., Neuschul, P.; Biochem. Zs. 281, 219 (1935); Chem. Abstr. 30, 1085 (1936). 42) Viljoen , Fred, Peterson: J. agr. sci., 16, 1 (1926). 43) Coolhaas, C.: Cent. Bakt. Perasit. II, 75, 344 (1928); Chem. Abstr., 23, 1152 (1929). 44)板野, 荒川: 日農化 5, 816 (昭4). 45) Groenwege, J.：Med. Genesk. Lac. Weltevreden; Chem. Abstr., 15, 2720 (1921). 46) Karrer, P.: Oppeheimer, C., Die Fermente und ihre Wirkung I, 505 (1936). 47) Heyes, T. F.: J. Soc. Chem. Ind. 47, 90-2T (1928); 化學實驗學第2部 天然物取扱法 III, 401 (昭17). 48) Bertho-Grassmann: Biochemisches Prakticum, 128 (1936). 49) Schaffer, P. A, Hattmann, A.F.: J. biol. chem. 45, 365 (1921). 50) 井上：榮研報告 10, 2-1 (眧16). 51) 宮本, 西澤：獸醫團報 336. 1 (昭17). 52) Kellermann-McBeth: Cent., Bakt. II, 34, 485 (1912). 53) Rene, J. Dubos: J. Bact.,15, 227 (1928). 54) Wallace, G. J., Neave, S. L.: J. Bact., 14. 377 (1927). 55) Bergey's mannual of determinative bacteriology 5th ed. (1939). 56) Waksman: The principles of soil microbiology, 197 (1927). 57) Rudolf, Weidenhagen: Methoden der Fementforschung Lieferung 6,1903 (1941). 